\title{
Strategi Pengembangan Pemasaran Beras Perusahaan Umum (Perum) Bulog di Kota Jambi
}

\author{
${ }^{1}$ Rizki Gemala Busyra dan ${ }^{2}$ Ali Anom \\ ${ }^{1}$ Dosen Program Studi Agribisnis Fakultas Pertanian Universitas Batanghari \\ ${ }^{2}$ Alumni Program Studi Agribisnis Fakultas Pertanian Universitas Batanghari \\ J1. Slamet Riyadi, broni Jambi. 36122. Telp. +6274160103 \\ 1e-mail korespondensi : rizki.gemala.busyra@unbari.ac.id
}

\begin{abstract}
The purpose of this study was to analyze the internal and external environment of Bulog rice marketing in Jambi City, to describe the marketing strategy of Bulog rice at the company level, and also to describe the 4 major strategies in Bulog rice marketing in Jambi City. This research was conducted at Perum Bulog, Jambi City in August 2019. The research used a quality and quantitative data. The type of data based on the measuring scale was is ordinal data and the data type based on time was it cross section data. The data collected in this study came from primary and secondary data. The data obtained were analyzed descriptively both quantitatively and qualitatively. The processing and analysis methods used were strategic management and marketing approaches by considering the changes of internal and external factors. Based on the IE(Internal External) matrix the results of the study show that the position of the marketing strategy at the company level was in cell III position because the total average IFE (Internal Factor Evaluation) was 1.6974 and the total average EFE (External Factor Evaluation) was 3.045, this indicates that Bulog must survive and maintain.
\end{abstract}

Keywords: development, Bulog Corporation, strategy

\begin{abstract}
Abstrak. Tujuan penelitian ini adalah untuk Menganalisis lingkungan internal dan eksternal pada pemasaran beras Bulog di Kota Jambi, mendeskripsikan strategi pemasaran beras bulog di tingkat perusahaan, dan menggambarkan 4 strategi besar dalam pemasaran beras Bulog di Kota Jambi. Penelitian ini dilaksanakan di Perum Bulog Kota Jambi. Peneitian ini menggunakan data kualitatif dan kuantitatif. Jenis data berdasarkan skala ukur adalah data ordinal dan data berdasarkan waktu adalah data Cross Section. Data yang dikumpulkan dalam penelitian ini bersumber dari data primer dan data sekunder. Data yang diperoleh dianalisis secara deskriptif baik kuantitatif maupun kualitatif. Metode pengolahan dan analisis yang digunakan adalah pendekatan manajemen strategis dan pemasaran dengan mempertimbangkan perubahan faktor-faktor internal dan eksternal. Berdasarkan matrik IE hasil penelitian menunjukkan bahwa posisi strategi pemasaran ditingkat perusahaan berada di sel III karena total rata-rata IFE 1.6974 dan total rata-rata EFE 3.045, hal ini mengindikasikan bahwa perum bulog harus bertahan dan memelihara
\end{abstract}

Kata kunci : kajian, pengembangan perum bulog, kota jambi

\section{PENDAHULUAN}

Pangan merupakan kebutuhan manusia sehingga ketersediaan pangan bagi masyarakat harus selalu terjamin. Dalam perkembangan peradaban masyarakat untuk memenuhi kualitas hidup yang maju, mandiri, dalam suasana tenteram serta sejahtera lahir dan batin semakin dituntut penyediaan pangan yang cukup, berkualitas dan merata. Beras merupakan salah satu bahan pangan pokok di Indonesia.

Kecukupan pangan (terutama beras) dengan harga yang terjangkau telah menjadi tujuan utama kebijakan pembangunan pertanian. Kekurangan pangan bisa menyebabkan kerawanan ekonomi, sosial, dan politik yang dapat menggoyahkan stabilitas nasional (Lim S, 2010). Untuk menjaga ketersediaan beras di Indonesia, perlu ditingkatkan peran dari masyarakat dan pemerintah daerah guna menjaga ketersediaan beras di tingkat nasional.

Perusahaan Umum Badan Urusan Logistik atau disingkat Perum Bulog merupakan sebuah lembaga pangan yang mengurusi tata niaga beras dan menjaga ketersediaan bahan-bahan pendukung guna melakukan produksi beras. Selama kurun waktu Januari hingga April 2019, baru sekitar 3.264.316 ton beras yang tersalurkan ke masyarakat dari target sebesar 17.672.400 ton beras untuk Propinsi Jambi. Ketersediaan beras akan mempengaruhi harga beras, selain itu harga beras juga dipengaruhi oleh harga barang lain serta kebijakan dari pemerintah (Agus, 2006).

Dalam melaksanakan tugasnya, Bulog menyelenggarakan fungsi pengkajian dan penyusunan kebijakan nasional di bidang manajemen logistik, pengadaan, pengelolaan persediaan, dan distribusi beras, serta pengendalian harga beras. Namun saat ini pihak swasta yang berusaha di sekor beras semakin ramai sehingga menggerus penerimaan Bulog. Persaingan usaha dengan pihak swasta memang tidak bisa dihindari sehingga perlu dicari upaya atau strategi pemasaran beras Bulog. Melihat latar belakang diatas, maka penulis tertarik untuk melakukan penelitian yang berjudul Strategi Pengembangan Pemasaran Beras Perusahaan Umum (Perum) Bulog di Kota Jambi. 


\section{METODE PENELITIAN}

Penelitian ini dilaksanakan di Perum Bulog Kota Jambi pada bulan Agustus 2019. Penelitian ini menggunakan data kualitatif dan kuantitatif. Jenis data berdasarkan skala ukur adalah data ordinal dan data berdasarkan waktu adalah data Cross Section. Data yang dikumpulkan dalam penelitian ini bersumber dari data primer dan data sekunder.

Data yang diperoleh dianalisis secara deskriptif baik kuantitatif maupun kualitatif. Metode pengolahan dan analisis yang digunakan adalah pendekatan manajemen strategis dan pemasaran dengan mempertimbangkan perubahan faktor-faktor internal dan eksternal. Data kuantitatif diolah dan disajikan dalam bentuk tabel.Berikut ini merupakan tahapan analisis data yang digunakan dalam penelitian :

A. Menentukan indikator kondisi lingkungan internal dan eksternal dengan cara mengumpulkan dari responden yang berkompeten, yaitu :

1. Kabid Pengembangan Bisnis dan Industri

2. Kabid Komersial

3. Kabid Pengadaan Operasional

4. Pimpinan Wilayah

5. Kabid Administrasi

B. Menentukan strategi yang tepat untuk dikembangkan ditingkat perusahaan, dengan cara menentukan bobot, rating dan skor dengan bantuan IFE dan EFE sebagai berikut :

Teknik Pembobotan

Penentuan bobot dilakukan dengan cara identifikasi faktor strategi internal dan eksternal kepada pihak manajemen dengan menggunakan metode paired comparison (David, 2006). Metode ini digunakan untuk memberikan penilaian terhadap bobot setiap faktor penentu internal dan eksternal dalam pemasaran beras bulog. Skala yang digunakan untuk kolom adalah : Nilai 1 jika indikator horizontal kurang penting dari pada indikator vertikal. Nilai 2 : Jika indikator horizontal sama penting dari pada indikator vertikal Nilai 3 : Jika indikator horizontal lebih penting dari pada indikator vertikal.

Bentuk dari penilaian dengan metode paired comparison untuk matriks IFE dan EFE dapat dilihat pada Tabel 2 dan 3 pada halaman berikut ini :

Tabel 1. Penilaian Bobot (absolut) Faktor Internal pemasaran beras bulog

\begin{tabular}{c|ccccccc}
\hline $\begin{array}{c}\text { Faktor } \\
\text { Strategi } \\
\text { Internal }\end{array}$ & A & B & C & D & E & Total \\
\hline A & & & & & & & \\
B & & & & & & & \\
C & & & & & & & \\
D & & & & & & \\
E & & & & & & \\
\hline Total & & & & & & \\
\hline
\end{tabular}

Sumber : David, 2006

Keterangan :

$\mathrm{A}=$ Sumber Daya manusia (SDM)

$\mathrm{B}=$ Lokasi Geografis

$\mathrm{C}=$ Penawaran

$\mathrm{D}=$ Harga Jual Produk

$\mathrm{E}=$ Pemasaran

Tabel 2. Penilaian bobot (absolut) Faktor Eksternal pemasaran beras bulog

\begin{tabular}{ccccc}
\hline Faktor Strategi Eksternal & A & B & C & Total \\
\hline A & & & & \\
B & & & & \\
C & & & \\
\hline Total & & & ₹xi \\
\hline
\end{tabular}

Sumber : David, 2006. 
Keterangan:

$\mathrm{A}=$ Kebijakan Pemerintah

$\mathrm{B}=$ Persaingan Produk Sejenis

$\mathrm{C}=$ Permintaan Pasar

Petunjuk pengisian :

Pilihan bobot pada daftar isian 2 terdiri dari:

$1=$ jika indikator horisontal kurang penting daripada indikator vertikal.

$2=$ jika indikator horisontal sama penting daripada indikator vertikal.

$3=$ jika indikator horisontal lebih penting daripada indikator vertikal.

Setelah bobot absolut diketahui selanjutnya ditentukan bobot relatif setiap variabel diperoleh dengan menentukan nilai setiap variabel terhadap jumlah keseluruhan variabel dengan menggunakan rumus (David, 2006) sebagai berikut :

Keterangan :

$$
\mathrm{a} i=\frac{X i}{\sum X i}
$$

ai $=$ Bobot variable ke $-\mathrm{i}$

$\mathrm{Xi}=$ Jumiah skor secara horizontal

$\sum x i=$ Jumlah skor secara vertikal

\section{Matriks Internal faktor Evaluation (IFE)}

IFE adalah analisis manajemen perusahaan terhadap faktor - faktor strategi internal utama berdasarkan daftar prioritas faktor - faktor tersebut (menggunakan bobot). Setelah faktor - faktor strategis internal diidentifikasi, maka suatu tabel IFE disusun untuk merumuskan faktor - faktor internal dalam kerangka kekuatan dan kelemahan usaha. Tahapan - tahapan itu adalah:

1. Tuliskan faktor internal seperti diidentifikasikan dalam proses audit internal, mencakup kekuatan dan kelemahan.

2. Berikan bobot yang berkisar dari 0,0 (tidak penting) hingga 1,0 (sangat penting) untuk masing - masing faktor. Bobot yang diberikan kepada masing masing - masing faktor mengindikasikan tingkat kepentingan relative dari faktor terhadap keberhasilan usaha. Tanpa menghiraukan apakah faktor kunci adalah kekuatan atau kelemahan internal. Faktor - faktor yang dianggap mempunyai pengaruh besar terhadap kinerja pemasaran diberi bobot tinggi. Jumlah dari semua bobot harus 1,0 .

3. Menghitung rating untuk masing untuk masing - masing faktor dengan memberikan skala mulai dari 1 sampai 4 berdasarkan pengaruh faktor - faktor tersebut terhadap kondisi bersangkutan. Variabel yang bersifat positif semua variabel yang masuk kategori kekuatan diberi nilai mulai dari 1 sampai 4 sangat baik dengan membandingkannya dengan rata-rata industri atau dengan pesaing utama sedangkan variabel yang bersifat negatif (kelemahan) kebalikannya contohnya jika kelemahan perusahaan besar sekali dibandingkan dengan ratarata industri nilainya 1 sedangkan jika kelemahan perusahaan di bawah rata-rata industri nilainya 4

4. Mengalikan bobot faktor dengan rating, untuk memperoleh skor pembobotan untuk masing - masing faktor.

5. Menjumlahkan nilai pembobotan untuk setiap variable untuk memperoleh total skor pembobotan skor bagi pengembangan pemasaran beras bulog. Total skor untuk matriks IFE berkisar antara 1,0 (terendah) hingga 4,0 (tertinggi) . Total skor lebih tinggi dari 2 menunjukan bahwa pengembangan pemasaran beras bulog dalam kondisi yang cukup baik, sedangkan total skor lebih rendah dari 2 menunjukan bahwa pemasaran dalam keadaan lemah. 
Contoh Matriks IFE dapat dilihat pada Table 3 berikut ini :

Tabel 3. Matriks Internal Evaluation (IFE)

\begin{tabular}{lccc}
\multicolumn{1}{c}{$\begin{array}{c}\text { Faktor Internal } \\
(\mathbf{1})\end{array}$} & $\begin{array}{c}\text { Bobot } \\
(\mathbf{2})\end{array}$ & $\begin{array}{c}\text { Rating } \\
(\mathbf{3})\end{array}$ & $\begin{array}{c}\text { Skor (2*3) } \\
(\mathbf{4})\end{array}$ \\
\hline Kekuatan & & & \\
1. & & & \\
2. & & \\
Kelemahan & & \\
1. & & & \\
2. & & $\mathbf{1 0 0}$ & \\
\hline
\end{tabular}

Sumber : David, 2006.

\section{Matriks Eksternal Faktor Evaluation (EFE)}

Menurut David (2006), matriks EFE membuat perencanaan strategi yang meringkas dan mengevaluasi informasi kebijaksanaan pemerintah, persaingan produk sejenis, dan permintaan pasar. Matriks EFE dapat dibuat dengan lima tahapan yaitu :

1. Tentukan faktor-faktor yang menjadi peluang dan ancaman usaha pemasaran beras bulog atau disebut lingkungan eksternal. Daftar peluang terlebih dahulu kemudian ancamannya.

2. Memberikan bobot dengan kisaran 0,0 (tidak penting), sampai 1,0 (terpenting) pada setiap faktor. Bobot yang diberikan pada suatu faktor menunjukan seberapa penting faktor tersebut menunjang keberhasilan usaha pemasaran beras bulog. Tetapi ancaman dapat juga menerima bobot tertinggi jika sangat mengancam. Jumlah seluruh bobot yang diberikan pada faktor diatas sama dengan 1,0.

3. Menghitung rating untuk masing - masing faktor dengan memberikan skala mulai 1 sampai 4 berdasarkan pengaruhi faktor - faktor eksternal terhadap kondisi usahatani. Skala peringkat yang digunakan yaitu, nilai $1=$ rendah, nilai $2=$ sedang, nilai $3=$ tinggi, nilai $4=$ sangat tinggi. Pemberian rating bersifat positif, peluang yang semakin besar diberi rating 4 tetapi jika peluangnya kecil diberi rating 1 pemberian nilai rating ancaman adalah kebalikannya misalnya Jika nilai ancaman yang sangat besar ratingnya 1 sebaliknya jika nilai ancamannya kecil ratingnya 4.

4. Mengalikan bobot dengan rating, untuk memperoleh skor pembobotan untuk masing - masing faktor

5. Menjumlahkan skor pembobotan untuk memperoleh total skor pembobotan usaha pemasaran beras bulog. Nilai total ini menunjukan bagaimana pemasaran beras bulog tersebut terhadap faktor-faktor strategis eksternalnya. Total skor matriks EFE berkisar antara 1,0 (terendah) sampai 4,0 (tertinggi). Total skor 1 menunjukan bahwa usahatani tidak mampu menghadapi ancaman yang ada dengan memanfaatkan peluang vang dimiliki, sedangkan totai skor 4 menunjukan bahwa usaha beras bulog komersil dapat bertahan dan tetap eksis daiam usahanya dengan semua peluang dan ancaman yang terjadi di dalam usahanva (David, 2006). Untuk lebih jelasnya Matriks Eksternal Evaluation dapat di lihat pada Tabel 4 berikut ini :

Tabel 4. Matriks Eksternal Evaluation (EFE)

\begin{tabular}{lcccc} 
& $\begin{array}{c}\text { Faktor Eksternal } \\
\text { (1) }\end{array}$ & $\begin{array}{c}\text { Bobot } \\
\text { (2) }\end{array}$ & $\begin{array}{c}\text { Rating } \\
\text { (3) }\end{array}$ & $\begin{array}{c}\text { Skor (2*3) } \\
\text { (4) }\end{array}$ \\
\hline Peluang & & & & \\
1. & & & \\
2. & & & \\
Ancaman & & & \\
1. & & & \\
2. & Total & & \\
\hline
\end{tabular}

Sumber : David, 2006.

\section{Tahap Pencocokan}

Matriks Internal Eksternai (IE)

Matriks IE menggambarkan bagaimana posisi suatu unit usaha dalam strategi pengembangan pemasaran beras bulog. Matriks IE didasari pada dua dimensi kunci yaitu total rata-rata timbangan IFE pada sumbu x dan total ratarata tertimbang EFE pada sumbu y. Pada sumbu vertikal, skor antara 1,00 sampai 1,99 pengaruh ekstemal yang 
rendah, skor 2,00 sampai 2,99 menunjukkan pengaruh eksternal yang sedang dan 3,00 sampai 4 menunjukkan pengaruh ekstemal yang tinggi. Untuk sumbu horizontal, skor antara 1,00 sampai 1,99 menunjukkan pengaruh internal yang lemah , 2,00 sampai 2,99 menunjukkan pengarah internal rata-rata dan skor 3,00 sampai 4 menunjukkan pengaruh internal yang kuat (David, 2006). Untuk lebih jelasnya matriks Internal Eksteral dapat dilihat pada Gambar 1 berikut ini:

\begin{tabular}{|c|c|c|c|c|}
\hline \multirow{6}{*}{$\begin{array}{l}\text { Total rata- } \\
\text { rata } \\
\text { tertimbang } \\
\text { EFE }\end{array}$} & \multicolumn{4}{|c|}{ Total rata-rata tertimbang IFE } \\
\hline & $3,00-4,00$ & $2,00-2,99$ & $1,00-1,99$ & \\
\hline & I & II & III & $3,00-4,00$ \\
\hline & & & & \\
\hline & IV & $\mathrm{V}$ & VI & $2,00-2,99$ \\
\hline & VII & VIII & IX & $1,00-1,99$ \\
\hline
\end{tabular}

Gambar 1. Matriks Internal Eksternal (IE)

Matriks IE dibagi rnenjadi tiga daerah utama yang memiliki implikasi strategi berbeda. Daerah pertama terdiri dari sel I, II dan IV dapat digambarkan sebagai tumbuh dan kembang (growth and build) strategi yang dapat mewakili antara lain strategi intensif ( penetrasi pasar, perluasan areal,dan perluasan produk) dan strategi integraxif (integrasi ke depan, integrasi ke belakang, dan integrasi horizontal). Daerah Kedua terdiri dari sel III, V, dan VII dapat dikelola dengan strategi hold dan maintain. Penetrasi pasar dan pengembangan produk usahatani adaiah dua strategi umum yang digunakan untuk devisi tipe ini. Daerah ketiga terdiri dari sel VI, VIII, IX dengan menggunakan strategi hervest or divest (pengembangan produk akuisi dan likuidasi). Gambar di atas menunjukkan Matriks Internal-Ekternal.

C. Menentukan 4 Strategi besar dalam pemasaran yang menggunakan analisis SWOT dengan mengikuti matrik berikut ini:

Untuk lebih jelasnya Matriks Analisis SWOT dapat di lihat pada Tabel 5 berikut pada halaman berikut ini:

Tabel 5. Matriks Analisis SWOT

\begin{tabular}{|l|l|l|}
\hline \multicolumn{1}{|c|}{ Faktor Internal } & $\begin{array}{l}\text { Strenght (S) } \\
\text { A. Penawaran } \\
\text { B. Harga Jual Produk } \\
\text { C. Pemasaran }\end{array}$ & $\begin{array}{l}\text { Weakness (W) } \\
\text { A. Sumber Daya manusia } \\
\text { (SDM) } \\
\text { B. Lokasi perum bulog } \\
\text { C. Penawaran } \\
\text { D. Harga Jual Produk } \\
\text { E. Pemasaran }\end{array}$ \\
\hline $\begin{array}{l}\text { Faktor Eksternal } \\
\begin{array}{l}\text { A. Kebijakan Pemerintah } \\
\text { B. Persaingan Produk Sejenis } \\
\text { C. Permintaan Pasar }\end{array}\end{array}$ & $\begin{array}{l}\text { Menentukan 4 Strategi } \\
\text { besar dalam pemasaran }\end{array}$ & $\begin{array}{l}\text { Menentukan 4 Strategi } \\
\text { besar dalam pemasaran }\end{array}$ \\
\hline $\begin{array}{l}\text { Threat (T) Menentukan faktor } \\
\text { A. Kebijakan Pemerintah } \\
\text { B. Persaingan Produk Sejenis }\end{array}$ & $\begin{array}{l}\text { Menentukan 4 Strategi } \\
\text { besar dalam pemasaran }\end{array}$ & $\begin{array}{l}\text { Menentukan 4 Strategi } \\
\text { besar dalam pemasaran }\end{array}$ \\
& & \\
\hline
\end{tabular}

Sumber : David, 2006. 


\section{Identitas Responden \\ Umur}

\section{HASIL PENELITIAN}

Umur merupakan salah satu indikator produktif atau tidaknya pengusaha dalam mengelola usahanya. Berdasarkan hasil penelitian didapatkan responden yang bervariasi. Untuk lebih jelasnya mengenai tingkat umur responden dapat disajikan pada Tabel 6.

Tabel 6. Distribusi Frekuensi Responden Berdasarkan Kelompok Umur Pada Tahun 2019.

\begin{tabular}{ccc}
\hline Umur (Tahun) & Frekuensi (Orang) & Persentase (\%) \\
\hline $33-39$ & 1 & 20 \\
$40-46$ & 2 & 40 \\
$47-53$ & 2 & 40 \\
\hline Total & $\mathbf{5}$ & $\mathbf{1 0 0}$ \\
\hline
\end{tabular}

Sumber : Hasil Olah Data 2020

Dari Tabel 5 diatas diketahui bahwa umur rata-rata responden adalah 44 tahun. Responden yang memiliki selang umur 40-46 tahun dan 47-53 tahun yang paling banyak frekuensinya di Perum bulog yaitu masing-masing sebanyak 2 orang atau $40 \%$ sementara responden paling sedikit frekuensinya adalah yang mamiliki selang umur 3339 tahun sebanyak $20 \%$ atau sebanyak 1 orang, Hal ini mengartikan bahwa di pengampu kebijakan di Perum bulog tidak didominasi oleh karyawan yang berusia lanjut atau yang berumur lebih produktif tapi masih diampu oleh karyawan yang mumpuni atau usia produkstif. Semakin muda usia seseorang maka pengalamannya juga belum banyak sebaliknya semakin tua atau matang usia seseorang maka orang tersebut dirasa mampu memahami permasalahan yang dihadapinya (Hamalik, 2006).

\section{Pendidikan}

Tingkat pendidikan dapat mempengaruhi cara berpikir dan kemampuan menyerap informasi dan teknologi, hal ini dapat dilihat semakin berkembangnya ilmu pengetahuan dan teknologi dibidang pemasaran maka sangat dibutuhkan keterampilan dan penguasaan teknologi tersebut. Berdasarkan hasil penelitian Tingkat pendidikan responden yang disajikan pada Tabel 7.

Tabel 7. Distribusi Frekuensi Responden Berdasarkan Tingkat Pendidikan Pada Tahun 2019.

\begin{tabular}{ccc}
\hline Pendidikan & Frekuensi (orang) & Persentase (\%) \\
\hline S1 & 3 & 60 \\
S2 & 2 & 40 \\
\hline Total & 5 & 100 \\
\hline
\end{tabular}

Sumber : Hasil Olah Data 2020

Dari tabel di atas terlihat bahwa frekuensi tingkat pendidikan terendah adalah jenjang S1 sebanyak 60\% atau 3 orang. Sedangkan frekuensi tingkat pendidikan tertinggi adalah jenjang S2 sebanyak $40 \%$ atau 2 orang. Tingkat pendidikan seseorang akan sangat berpengaruh terhadap cara berpikir, menerima dan mencoba hal-hal baru.

Pendidikan mempengaruhi karyawan dalam mengelola pekerjaannya, karena tingkat pendidikan dan pengetahuan seseorang akan membantu untuk berpikir global dan penuh pertimbangan. Namun menurut Hernanto dalam Ranti (2009) bahwa rendahnya tingkat pendidikan formal yang ada pada seseorang dapat diatasi dengan memberikan kesempatan untuk melanjutkan ke jenjang yang lebih tinggi. Selain pendidikan formal, juga bisa melalui pendidikan non formal. Pendidikan non formal yaitu meningkatkan pembinaan melalui penyuluhan, pelatihan dan kursus karena penyuluhan adalah pendidikan non formal yang dapat diterapkan dan diikuti karyawan. Penyuluh dapat berperan dalam memberikan pengetahuan, keterampilan, pembangunan pola pikir, prilaku dalam aktivitas sehari-hari. Menurut Nurhayati dan Sahara dalam Ranti (2009), bahwa semakin tinggi tingkat pendidikan seseorang, maka akan cepat tanggap terhadap perkembangan teknologi dan kemampuan seseorang.

\section{Pengalaman Kerja}

Pengalaman kerja merupakan salah satu faktor yang berperan penting dalam berusaha. Pengalaman kerja responden di ukur dalam tahun, sejak pertama kali bekerja di Perum Bulog. Pengalaman kerja berpengaruh terhadap keterampilan sesorang dalam mengelola pekerjaannya. Biasanya orang yang telah berpengalaman dalam bekerja akan terlihat lebih terampil dalam melakukan pekerjaannya dari pada orang yang kurang pengalaman. Untuk lebih jelasnya pengalaman kerja responden di Perum Bulog dapat dilihat pada Tabel 8. 
Tabel 8. Distribusi Frekuensi Responden Berdasarkan Pengalaman Kerja Pada Tahun 2019.

\begin{tabular}{ccc}
\hline Lama Kerja (tahun) & Frekuensi (orang) & Persentase (\%) \\
\hline $\mathbf{1 0 - 1 4 , 3}$ & 3 & 60 \\
$\mathbf{1 4 , 4 - ~ 1 8 , 7}$ & 0 & 0 \\
$\mathbf{1 8 , 8 - 2 3 , 1}$ & 2 & 40 \\
\hline Total & 5 & 100 \\
\hline
\end{tabular}

Sumber : Hasil Olah Data 2020

Dari tabel di atas terlihat bahwa frekuensi pengalaman kerja terendah adalah pada rentang 10-14,3 tahun sebanyak $60 \%$ atau 3 orang. Sedangkan frekuensi pengalaman kerja tertinggi adalah pada rentang 18,8-23,1 tahun sebanyak $40 \%$ atau 2 orang dengan rata-rata pengalaman kerja adalah sebanyak 16 tahun 4 bulan.

Kondisi Lingkungan Internal dan Eksternal untuk menyusun strategi pemasaran beras bulog di tingkat perusahaan :

\section{Kondisi Lingkungan Internal}

Lingkungan internal adalah suatu lingkungan yang berada dalam organisasi yang secara langsung berpengaruh pada kinerja organisasi. Aspek - aspek teknis dalam lingkungan internal Bulog Kota Jambi yang merupakan kekuatan dan kelemahannya yaitu sumber daya manusia, lokasi usaha, penawaran, harga jual beras, tenaga kerja, dan pemasaran. Aspek - aspek ini besar sekali pengaruhnya terhadap kelancaran jalannya pemasaran beras bulog Kota Jambi. Untuk lebih jelasnya kondisi lingkungan internal pemasaran beras bulog Kota Jambi dapat di lihat sebagai berikut :

\section{Sumber Daya Manusia}

Manusia adalah sebagai penggerak vital dalam melakukan pemasaran beras bulog, karena manusia penentu perencana, pelaku dan penentu terwujudnya tujuan organisasi Bulog. Sumber daya manusia sangat menentukan dalam pengelolaan beras bulog Kota Jambi.

a. Tingkat Pendidikan Tenaga Kerja

Tingkat pendidikan karyawan Perum Bulog bulog Kota Jambi mayoritas adalah berpendidikan SMA/SMK.

b. Keterampilan Tenaga Kerja

Dari hasil kuisioner, sebagian besar karyawan memiliki keterampilan yang cukup terampil dalam memasarkan beras bulog. Secara keseluruhan pada aspek Sumber Daya manusia (SDM) Perum Bulog Kota Jambi menunjukan suatu kelemahan dalam upaya pengembangan pemasaran berasnya dilihat dari rendahnya pendidikan, keterampilan yang cukup dan kebanyakan karyawannya berjenis kelamin laki-laki. Dimana diketahui bahwa wanita lebih pintar memikat calon pembeli daripada laki-laki.

\section{Lokasi Usaha}

a. Ketersediaan Beras Bulog di Pasar

Beras bulog baru tersedia pada pasar-pasar tradisional, ini terlihat dari nilai bobot 0,145 . Sedangkan di kota Jambi, terdapat banyak Mall dan minimarket serta pasar modern yang secara tidak langsung mempengaruhi pemasaran beras bulog, karena pasar tradisional buka hingga jam 4 sore sedangkan pasar modern buka hingga jam 10 malam. Kebanyakan masyarakat kota jambi yang bekerja siang hari pergi berbelanja dari sore hingga malam hari.

b. Jarak Lokasi Perum Bulog dilihat dari Akses Transportasi

Keberadaan lokasi perum bulog di lihat dari jaraknya, pada umumnya sangat dekat dari akses transportasi jalan raya dan dekat dengan pangsa pasar dengan sarana yang sangat memadai. Secara keseluruhan pada aspek lokasi usaha Perum Bulog Kota Jambi menunjukan suatu kekuatan.

\section{Penawaran}

Penawaran adalah sejumlah barang dan jasa yang sanggup ditawarkan oleh produsen pada tingkatan harga dan waktu tertentu. Penawaran dalam penelitian ini penawaran dilihat dari Kegiatan penawaran (operasi pasar, bazar), Kualitas dan kuantitas produk yang ditawarkan serta kemasan (bentuk, ukuran, design).

A. Operasi pasar dan bazar

Perum Bulog Kota Jambi sangat sering melakukan operasi pasar dan bazar, ini terlihat dari nilai bobot 0,0637 yang mengindikasikan bahwa kegiatan operasi pasar dan bazar memiliki derajat kepentingan yang sama untuk dipertimbangkan. Hal ini merupakan kekuatan yang harus dipertahankan dan hal ini terbukti dengan seringnya mobil-mobil yang berspanduk operasi pasar Bulog Kota Jambi di pasar-pasar kecil di Kota Jambi seperti pasar Perum Aurduri, Pasar Olak Kemang, Pasar Kasang dan lain - lain. 


\section{B. Kualitas Beras Bulog}

Beras yang ditawarkan oleh bulog memiliki kualitas dan kuantitas yang berada dibawah kualitas dan kuantitas beras komersil lain yang beredar di kota jambi. Ini terlihat dari nilai bobot 0,1092, untuk itu perlu upaya untuk meningkatkan kualitas dan kuantitas dari permasalahan tersebut.

C. Kemasan

Variasi dan design kemasan beras bulog cukup beragam dan menarik, ukuran kemasan bervariasi mulai dari $10 \mathrm{~kg}, 5 \mathrm{~kg}$ dan $200 \mathrm{gr}$ kemasan (renceng) yang mana lebih ekonomis dari segi ukuran. Selain itu bentuk berasnya juga bagus dan beras bulog telah terfortifikasi dan diperkaya dengan vitamin dan mineral. Kemasan mempunyai nilai bobot 0,0637 yang mengindikasikan bahwa desain kemasan memiliki derajat yang penting terhadap pengembangan pemasaran beras bulog di Kota Jambi.

Secara keseluruhan pada aspek penawaran beras bulog Kota Jambi menunjukan suatu kekuatan dalam pengembangan strategi pemasaran beras bulog.

\section{Penetapan Harga Jual Beras}

Aspek pemasaran beras bulog memiliki kekuatan dengan nilai bobot 0,0356 . Penetapan harga jual beras bulog lebih rendah dibandingkan beras lain di pasaran karena penetapan harga ditentukan oleh pemerintah, namun disisi lain hal ini untuk menjaga stabilitas harga sehingga masyarakat yang berekonomi lemah tidak kuatir atas naiknya harga beras.

\section{Pemasaran}

Pemasaran adalah salah satu kegiatan pokok yang perlu dilakukan dalam usaha baik itu dalam upaya untuk mempertahankan kelangsungan hidup usahanya. Hal tersebut disebabkan karena pemasaran merupakan salah satu kegiatan usaha, di mana secara langsung berhubungan dengan konsumen. Maka kegiatan pemasaran dapat diartikan sebagai kegiatan manusia yang berlangsung dalam kaitannya dengan pasar.

a. Kondisi Pangsa Pasar Beras Bulog

Pangsa pasar beras bulog belum mencapai seluruh lapisan masyarakat Kota Jambi yang diwakili dengan nilai bobot 0,1221 menunjukkan bahwa derajat kepentingan kondisi pasar beras bulog kurang dalam pengembangan pemasarannya . Ini ditandai dengan kurangnya ketersediaan beras bulog di pasar-pasar modern (mall) di Kota Jambi.

b. Besarnya Pangsa Pasar Beras Bulog

Dengan jumlah masyarakat Kota Jambi sebanyak 583.487 jiwa maka perlu upaya untuk meningkatkan persentase pangsa pasar beras bulog sehingga menutupi seluruh lapisan masyarakat Kota Jambi. Dengan nilai bobot 0,1171 menunjukkan bahwa Bulog harus meningkatkan promosinya ke seluruh wilayah Kota Jambi.

c. Pasar Tujuan Beras Bulog

Beras bulog hanya dipasarkan di pasar tradisional dan kios-kios disetiap kantor bulog Kota Jambi dan beberapa kios di pemukiman masyarakat. Tapi beras bulog tidak tersedia disemua pasar modern dan pasar semi modern. Hal ini merupakan kelemahan yang ditunjukkkan dengan nilai bobot 0,1171.

Secara keseluruhan pada aspek pemasaran beras bulog Kota Jambi menunjukan suatu kelemahan sehingga dibutuhkan upaya yang harus dilakukan dalam pengembangan strategi pemasaran beras bulog.

\section{Kondisi Lingkungan Eksternal}

Lingkungan eksternal adalah lingkungan di luar organisasi yang memiliki kekuatan diluar kendali organisasi dan apabila terjadi perubahan-perubahan terhadapnya akan dapat mempengaruhi kinerja organisasi. Pertumbuhan dan perkembangan suatu organisasi tidak terlepas dari kondisi lingkungan eksternal. Lingkungan eksternal merupakan faktor penting yang perlu dikaji dalam penentuan pengambilan suatu keputusan. Pengenalan dan pemahaman tentang berbagai kondisi serta dampaknya menjadi hal mutlak yang harus ditelaah lebih lanjut. Oleh karena itu penting bagi suatu organisasi untuk menyesuaikan diri dari lingkungan eksternalnya.

\section{Kebijakan Pemerintah}

a. Kebijakan dalam aspek pemasaran yang berkaitan dengan strategi pemasaran

Dari hasil penelitian terlihat bahwa kebijakan dalam aspek pemasaran yang berkaitan dengan strategi pemasaran masih memiliki peluang. Pemerintah mempunyai tanggung jawab untuk melindungi pelaku usaha dari berbagai bentuk ancaman terhadap keberlanjutan produksi dan kesejahteraan pelaku usaha. Karena begitu berperannya sektor usahatani bagi suatu bangsa maka tidak terlepas dari kepentingan semua pihak sehingga program pemerintah terhadap pertanian sering mengalami konflik, namun pada dasarnya program pemerintah adalah untuk melindungi dan meningkatkan pendapatan petani. 
b. Kebijakan Pemerintah dalam Upaya Meningkatkan Daya Saing

Bentuk kepedulian pemerintah dalam upaya peningkatan daya saing beras bulog menunjukkan peluang yang ditunjukkan dengan nilai bobot sebesar 0,31. Upaya yang telah dilakukan dalam bentuk antara lain telah melakukan promosi, membuat kemasan yang lebih menarik, dari segi design dan ukuran yaang lebih ekonomis dan hemat. Dari hasil penelitian di lapangan untuk faktor eksternal secara keseluruhan pada aspek kebijakan pemerintah dalam mendukung usaha beras bulog menunjukan suatu Peluang dalam upaya pengembangan pemasarannya.

\section{Persaingan Produk Sejenis}

a. Perbandingan Harga Beras Bulog Dengan Harga Beras Pesaing Lainya

Dari hasil penelitian yang menunjukan bahwa harga beras bulog lebih rendah dibanding dengan harga beras pesaing lainnya yang ditunjukkan dengan nilai bobot sebesar 0,31. Adapun harga beras bulog dengan kategori rendah adalah sebesar RP. 9.242/kg, kategori medium adalah seberas Rp. 9.434/kg dan kategori premium adalah sebesar Rp. 9.659/kg dan harga beras renceng (200 gr/bks adalah Rp. 2.500), sedangkan harga beras lainnya berkisar di atas RP. 10.000/kg hingga Rp. $12.500 / \mathrm{kg}$. Hal ini menunjukkan peluang yang sangat besar karena mempunyai nilai pasar yang tinggi dan merupakan kekuatan dalam usaha.

b. Persaingan Harga Beras Bulog dengan Beras Pesaing

Persaingan harga beras bulog dengan beras pesaing lainnya menunjukan masih lebih unggul dengan nilai bobot $0,31 \mathrm{Hal}$ ini menunjukkan peluang yang tinggi karena harga beras bulog lebih ekonomis dari beras lain yang tersedia di Kota Jambi. Secara keseluruhan untuk faktor eksternal pada aspek perbandingan dan persaingan produk sejenis dalam mendukung usaha beras bulog menunjukkan suatu peluang dalam upaya pengembangan pemasaran beras bulog Kota Jambi.

\section{Permintaan Pasar}

\section{a. Tingkatan Harga Beras Bulog Kota Jambi Saat Penelitian}

Dari hasil penelitian di lapangan harga beras bulog harga produk saat penelitian ini dilakukan berkisar antara Rp. 9.659,- sampai Rp. 9.242,- per kilogramnya.kemudian ada beras renceng yang di jual Rp. 2.500,per bungkus (200 gr). Harga ini lebih rendah di bandingkan harga beras lainnya dan ini merupakan peluang yang harus dapat dimanfaatkan dalam menyususn strategi pengembangan pemasaran beras bulog.

\section{b. Volume permintaan Beras Bulog}

Permintaan pasar akan beras bulog dalam setahun terakhir meningkat karena musim kemarau serta peningkatan jumlah penduduk, yang berarti peluang yang harus bisa dimanfaatkan dimana bulog memiliki stok yang tidak terbatas artinya bulog Kota Jambi mampu memenuhi permintaan masyarakat Kota Jambi.

c. Perkembangan Permintaan Beras Bulog 3 Bulan Terakhir

Pengukuran permintaan pasar memperlihatkan pemahaman yang jelas akan pasar yang tercakup di dalamnya. Permintaan beras bulog tiga bulan terakhir ini masih stabil artinya permintaan selalu ada. Secara keseluruhan untuk faktor eksternal pada aspek permintaan pasar dalam mendukung pengembangan pemasaran beras bulog menunjukan suatu peluang dalam upaya strategi pengembangan.

\section{Strategi Pemasaran Beras Bulog di Tingkat Perusahaan.}

Berdasarkan matrix IE, menunjukkan bahwa strategi pemasaran ditingkat perusahaan berada di sel III dengan nilai total rata-rata tertimbang IFE 1.6974 dan total rata-rata tertimbang EFE 3.045 (Lampiran 16) maka secara operasional Bulog dapat mengandalkan empat strategi pokok, yaitu:

1. Strategi dorong tarik, yaitu mendorong agar petani mau langsung menjual ke BULOG. Caranya, BULOG memberikan beberapa layanan menarik seperti menyediakan gudang, kemudahan pembayaran dan memberikan insentif karung.

2. Strategi jaringan semut. Yaitu Jika dulu BULOG membeli beras dari para pelaku bisnis besar, sekarang BULOG membeli langsung dari kelompok tani, petani perorangan dan berbagai penggilingan skala kecil. Manfaat utama jaringan semut adalah, mata rantai BULOG dengan produsen menjadi lebih pendek, sehingga proses pengadaan beras lebih cepat dan produsen atau petani memperoleh harga yang wajar.

3. Strategi Insentif, di mana daerah yang defisit beras bisa membeli langsung dari daerah produsen dengan harga berbeda, tetapi tidak boleh lebih tinggi dari harga BULOG yang mengangkut beras dari daerah produsen ke daerah defisit. Strategi ini memberi keuntungan ganda, bagi perusahaan dan masyarakat. Daerah defisit dapat melakukan pembelian gabah/beras dengan harga lebih tinggi dari HPP, namun tambahan harga yang diberikan dalam bentuk insentif tersebut tidak lebih dari $80 \%$ biaya move jika beras dikirim dari divre produsen. 
4. Strategi on Farm, yaitu kerjasama langsung dengan petani yang mengolah hasil panennya di tempat BULOG seperti menjemur untuk mengeringkan gabah dan sekaligus menggilingnya di tempat BULOG. Kerjasama ini juga semakin memotong mata rantai sehingga petani akan mendapatkan nilai tambah.

Analisis SWOT digunakan untuk menganalisis strategi pengembangan pemasaran beras bulog dalam lingkungan internal maupun eksternalnya, yang bertujuan untuk mendeteksi serta merumuskan kebijaksanaan yang sifatnya strategi bagi pemasarannya.

\section{Identifikasi Lingkungan Internal pada Beras Bulog Kota Jambi}

Hasil penelitian yang dilakukan penulis pada Perum Bulog Kota Jambi adalah menggunakan alat analisis SWOT. Analisis SWOT dilakukan untuk mengetahui kekuatan dan kelemahan usaha, peluang dan ancaman. Untuk mengetahui kekuatan dan kelemahan dilakukan analisis kondisi lingkungan internal sedangkan untuk mengetahui peluang dan ancaman dengan manganalisis kondisi lingkungan ekternal.

Pengembangan pemasaran beras bulog Kota Jambi berdasarkan kondisi internal memiliki kekuatan dan kelemahan dalam pelaksanaan pengembangannya. Sedangkan secara eksternal juga menghadapi berbagai peluang yang dapat dimanfaatkan serta ancaman yang perlu dihindarkan.

\section{Kekuatan}

Dari hasil penelitian, pemasaran beras bulog mempunyai prospek yang cukup besar untuk dapat dikembangkan. Perum Bulog Kota Jambi memiliki faktor - faktor yang mampu mendukung usaha pengembangannya. Faktor - faktor pendukung dalam penelitian dinamakan kekuatan.

Adapun kelima faktor kekuatan yang dimiliki Perum Bulog Kota Jambi yaitu :

1. Kegiatan penawaran beras bulog dilakukan melalui operasi pasar dan bazar

2. Memiliki ukuran kemasaran yang hemat dan ekonomis (200 gr/bks)

3. Penetapan harga jual beras bulog di pasaran lebih rendah di bandingkan beras lain di pasaran.

4. Letak geografis produsen Bulog berada ditengah kota yang didukung sarana prasarana yang memadai.

5. Adanya dukungan pemerintah dalam upaya meningkatkan daya saing produk beras bulog dan bantuan sarana prasarana lainnya Harga jual beras bulog lebih rendah dibandingkan produk sejenis

\section{Kelemahan}

Dari hasil penelitian di lapangan, Perum Bulog Kota Jambi memilki beberapa faktor penghambat dalam pengembangan usaha.

Adapun enam faktor penghambat tersebut merupakan kelemahan yang dimiliki, kelemahan tersebut yaitu :

1. Sumber Daya Manusia (SDM), mayoritas pendidikan hanya pada tingkatan SMA/SMK.

2. Keterampilan tenaga kerja masih kurang memadai.

3. Beras Bulog Kota Jambi belum tersedia di Seluruh pasar di Kota Jambi, baru tersedia di pasar tradisonal dan beberapa kios.

4. Kualitas beras yang ditawarkan masih dibawah kualitas beras pesaing

5. Kondisi pangsa pasar dan besarnya pangsa pasar beras bulog masih belum menyentuh seluruh lapisan di Kota Jambi.

Kelima variabel ini perlu mendapatkan perhatian yang serius dalam upaya mengembangkan pemasaran beras bulog Kota Jambi.

\section{Identifikasi Lingkungan Eksternal Pada Beras Bulog Kota Jambi \\ 1. Peluang}

Berdasarkan hasil penelitian ke lapangan terdapat beberapa faktor eksternal (peluang dan ancaman) yang telah diidentifikasi dalam menyusun strategi pengembangan beras bulog Kota Jambi. Terdapat tiga peluang dalam pemasaran beras bulog ini adalah:

a. Permintaan pasar, permintaan pasar akan produk beras Bulog terus meningkat seiring dengan pertambahan jumlah penduduk.

b. Meningkatnya jumlah supermarket dan minimarket.

\section{Ancaman}

Ancaman dalam pemasaran beras bulog ini adalah:

1. Impor beras dengan jumlah yang cukup besar yang dilakukan pemerintah

2. Pemanasan global yang akan membuat gagal panen dari petani binaan bulog

3. Banyaknya merk dari produk sejenis yang sudah tersedia di pasaran. 


\section{Empat Strategi Besar Dalam Pemasaran Beras Bulog Di Kota Jambi}

a. Strategi S-O

1. Menambah kapasitas penawaran ke pangsa pasar baru (minimarket dan supermarket)

2. Meningkatkan frekuensi kegiatan penawaran beras melalui operasi pasar dan bazar

3. Mengoptimalkan dukungan pemerintah yang sudah berjalan untuk meningkatkan pemasaran

b. Strategi $\mathrm{S}-\mathrm{T}$

1. Memasang strategi untuk memperbaiki daya tarik produk (kemasan dan kualitas penjualan yang lebih terjangkau)

2. Mempertahankan posisi harga untuk menghadapi produk impor

3. Antisipasi gagal panen dengan mengontrol stok yang mendukung pemasaran.

c. Strategi W-O

1. Meningkatkan kualitas sumberdaya dan memperluas pangsa pasar dengan menambah frekuensi operasi pasar dan bazar.

2. Memfocuskan pada peningkatan kualitas beras dengan mengoptimalkan dukungan pemerintah.

d. Strategi W - T

1. Meningkatkan kualitas beras dan mempertahankan harga

2. Meningkatkan kualitas sumberdaya dalam kontroling stok.

\section{KESIMPULAN}

1. Lingkungan ekternal dan internal beras bulog Kota Jambi

Kegiatan penawaran beras bulog dilakukan melalui operasi pasar dan bazar, beras bulog memiliki ukuran kemasaran yang hemat dan ekonomis (200 gr/bks), penetapan harga jual beras bulog di pasaran lebih rendah di bandingkan beras lain di pasaran, Sumber Daya Manusia (SDM), mayoritas pendidikan karyawan hanya pada tingkatan SMA/SMK, Keterampilan tenaga kerja masih dalam kategori cukup, Beras Bulog Kota Jambi belum tersedia di Seluruh pasar di Kota Jambi, baru tersedia di pasar tradisonal dan beberapa kios, Letak geografis produsen Bulog berada ditengah kota yang didukung sarana prasarana yang memadai,, Kualitas beras yang ditawarkan masih dibawah kualitas beras pesaing, Kondisi pangsa pasar dan besarnya pangsa pasar beras bulog masih belum menyentuh seluruh lapisan di Kota Jambi, Adanya dukungan pemerintah dalam upaya meningkatkan daya saing produk beras bulog dan bantuan sarana prasarana lainnya Persaingan produk sejenis, dimana harga jual beras bulog lebih rendah di banding produk pesaing lainnya, Harga jual beras bulog lebih rendah dibandingkan produk sejenis, Permintaan pasar, permintaan pasar akan produk beras terus meningkat,terlebih dengan kondisi musim kemarau yang menyebabkan permintaan beras meningkat serta peningkatan jumlah penduduk, yang tidak kalah penting adalah tingkatan harga jauh lebih rendah dibandingkan dengan harga beras lainnya. Ini menunjukan bahwa beras bulog lebih murah dibandingkan beras pesaing lain, Impor beras dengan jumlah yang cukup besar yang dilakukan pemerintah, Pemanasan global yang akan membuat gagal panen dari petani binaan bulog.

2. Berdasarkan matrik IE posisi strategi pemasaran ditingkat perusahaan berada di sel III karena total rata-rata IFE 1.6974 dan total rata-rata EFE 3.045, hal ini mengindikasikan bahwa perum bulog harus bertahan dan memelihara.

3. 4 strategi besar dalam pemasaran beras Bulog di Kota Jambi yaitu :

a. Strategi S-O

1. Menambah kapasitas penawaran ke pangsa pasar baru (minimarket dan supermarket)

2. Meningkatkan frekuensi kegiatan penawaran beras melalui operasi pasar dan bazar

3. Mengoptimalkan dukungan pemerintah yang sudah berjalan untuk meningkatkan pemasaran

b. Strategi $\mathrm{S}-\mathrm{T}$

1. Memasang strategi untuk memperbaiki daya tarik produk (kemasan dan kualitas penjualan yang lebih terjangkau)

2. Mempertahankan posisi harga untuk menghadapi produk impor

3. Antisipasi gagal panen dengan mengontrol stok yang mendukung pemasaran.

c. Strategi W-O

1. Meningkatkan kualitas sumberdaya dan memperluas pangsa pasar dengan menambah frekuensi operasi pasar dan bazar.

2. Memfocuskan pada peningkatan kualitas beras dengan mengoptimalkan dukungan pemerintah.

d. Strategi W - T

1. Meningkatkan kualitas beras dan mempertahankan harga

2. Meningkatkan kualitas sumberdaya dalam kontroling stok. 


\section{DAFTAR PUSTAKA}

Abdi,Usman Rianse. 2012. Metodologi Penelitian Sosial dan Ekonomi. Alfabeta. Bandung.

Basu Swastha. 2008. Menejemen Pemasaran Modern. Penerbit Liberty.Yogyakarta.

David, F.R. 2006. Manajemen Strategis. Edisi kesepuluh. PT. Salemba Empat. Jakarta.

Firdaus, Muhammad.2008. Manajemen Agribisnis. Bumi Aksara. Jakarta.

Gitosudarmo I, 2018. Manajemen Strategis. BPFE. Yogyakarta.

Hamalik, Oemar, 2006. Proses Belajar Mengajar. PT. Bumi Aksara, Jakarta.

Haryani D. 2009. Analisis Efisiensi Usahatani Padi Sawah Pada Program Pengelolaan Tanaman dan Sumberdaya Terpadu di Kabupaten Serang Provinsi Banten. (tesis). Bogor. Institut Pertanian Bogor.

Kotler, P. 2000. Manajemen Pemasaran. Prenhallindo. Jakarta.

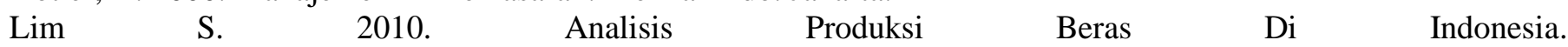
http://journal.binus.go.id/index.php/BBR/article/viewFile/1072/938

Marzuki dan Sawitri N. 2018. Strategi Pemasaran Beras Kotabaru Reteh Kecamatan Keritang (Studi Kasus Penggilingan Jayabakti). http://ejournal.unisi.ac.id/index.php/agribisnis/article/view/169

Moh. Nazir. 2003. Metode Penelitian. Alfabetis. Bandung.

Rangkuti, Freddy. 2018. Teknik Membedah Kasus Bisnis Analisis SWOT. PT. Gramedia Pustaka Utama, Jakarta.

Salastina, A. 2010. Strategi Pengembangan Usaha Beras (Studi Kasus Pb. Sugih Mukti, Kabupaten Cianjur). Skripsi. Institut Pertanian Bogor.

Sianturi F. 2016. Analisis Strategi Pemasaran Beras Pada Cv. Rejeki Jaya Panombeian.http://repository.usu.ac.id/bitstream/handle/123456789/66212/Cover.pdf?sequence=7\&isAllow ed $=y$

Sudiyono, A. 2004. Pemasaran Pertanian. UMM Press. Malang.

Umar, H. 2005. Strategic Management In Action. Gramedia Pustaka Utama. Jakarta.

Winarno, S. 1994. Pengantar Penelitan Ilmiah (dalam Metode Teknik). Kanisius. Bandung 